\title{
ANALISIS KELAYAKAN FINANSIAL DAN RISIKO USAHA BUDIDAYA JAMUR TIRAM DI PROVINSI LAMPUNG
}

(Financial Feasibility and Risk Analysis of Oyster Mushroom Cultivation Business in Lampung Province)

Jenisa Devy, Ali Ibrahim Hasyim, Suriaty Situmorang

Jurusan Agribisnis, Fakultas Pertanian, Universitas Lampung, Jl. Prof. Dr. Soemantri Brodjonegoro No. 1

Bandar Lampung 35145, Telp. 085768483747, e-mail: jenisadevy04@gmail.com

\begin{abstract}
This research aims to analyze the financial feasibility and the risk of oyster mushroom cultivation which is conducted in Lampung Province, especially in Metro and Bandar Lampung City. The locations of the research are chosen purposively by considerating that both places were the largest harvesting areas and the highest oyster mushroom production. The data is collected in month of May 2017, in which respondents are taken by census method with the amount of seven cultivators. They are divided into three categories based on their techniques they use, i.e., the cultivators producing the planting media to be cultivated and partly to be sold, the cultivators producing the planting media to be cultivated only, and the cultivators purchasing the planting media to be cultivated. Furthermore, the financial and risk analyses are analyzed by the quantitative analysis. The result showed that the oyster mushroom cultivation on the three categories were profitable and feasible to be developed based on the value of investment criterias (Internal Rate of Return (IRR), Net Present Value (NPV), Payback Period (PP), Gross Benefit Cost Ratio (Gross B/C Ratio) and Net Benefit Cost Ratio (Net B/C Ratio)). The risk analysis showed that CV (Coefficient of Variation) value was $\leq$ $0,5$ and value of lower limit ( $L)$ was $\geq 0$; hence the cultivators were able to avoid the risk.
\end{abstract}

Key words : cultivator, feasibility, financial, oyster mushroom, risk

\section{PENDAHULUAN}

Komoditas hortikultura, khususnya sayuran dan buah-buahan berperan penting dalam keseimbangan pangan, yaitu dalam pemenuhan protein nabati, serat dan vitamin, sehingga harus tersedia dalam jumlah yang cukup, mutu yang baik, harga yang terjangkau dan dapat diakses oleh seluruh masyarakat. Jamur tiram merupakan salah satu komoditas hortikultura yang bergizi tinggi dan potensial untuk dikembangkan. Menurut Chazali dan Pratiwi (2009), jamur tiram merupakan jenis sayuran organik yang penting dalam pemenuhan kebutuhan manusia, namun jumlahnya masih sedikit, yaitu produksinya ternyata baru bisa memenuhi 50 persen dari permintaan pasar dalam negeri, sehingga budidaya jamur perlu dikembangkan sebagai upaya pemenuhan permintaan jamur tiram untuk pasar dalam negeri.

Dalam perkembangannya budidaya jamur tiram sudah banyak dikembangkan di berbagai daerah di Indonesia. Sentra penghasil jamur terbesar berada di Pulau Jawa, khususnya Jawa Barat dan DIY Yogyakarta, sedangkan untuk Pulau Sumatera, daerah yang potensial untuk dikembangkan budidaya jamur tiram adalah Provinsi Lampung, dengan luas panen seluas $70.327 \mathrm{~m}^{2}$ di tahun 2015
(Kementerian Pertanian 2016). Pemasok jamur tiram terbesar di Provinsi Lampung berada di Kota Metro dan Bandar Lampung.

Menurut Dinas Pertanian Tanaman Pangan dan Hortikultura (2016), sebagai pemasok jamur tiram terbesar, Kota Metro dan Kota Bandar Lampung juga mengalami permasalahan terkait penurunan produktivitas jamur tiram. Pada tahun 2015, Kota Metro mengalami penurunan produktivitas jamur tiram 6,54 persen, sedangkan Kota Bandar Lampung mengalami penurunan produktivitas jamur tiram 5,15 persen. Penurunan produktivitas jamur tiram tersebut diakibatkan oleh semakin menurunnya jumlah pelaku usaha jamur tiram, karena kurangnya modal, keterampilan, serta pengetahuan budidaya, sehingga menyebabkan pembudidaya mengalami kegagalan dalam usahanya.

Salah satu hal yang menjadi pendorong utama masyarakat untuk melakukan budidaya jamur tiram adalah budidaya jamur menghasilkan panen jamur tiram harian yang dapat langsung dijual, sehingga pembudidaya cepat memperoleh penerimaan. Namun, di sisi lain, pembudidaya seringkali tidak memperhitungkan kemungkinan risiko yang terjadi pada usaha budidaya jamur tiramnya dan akibatnya 
pembudidaya tidak memperoleh keuntungan atau mengalami kerugian. Dengan demikian hubungan kalayakan usaha secara finansial dan risiko akan menjadi pengetahuan penting bagi pembudidaya sebagai dasar pertimbangan yang rasional dalam mengembangkan budidaya jamur tiram.

Subyek pada penelitian ini adalah pembudidaya jamur yang masih aktif dan kontinu dalam memproduksi jamur tiram di daerah Kota Metro dan Kota Bandar Lampung yang memiliki potensi jamur tiram terbesar, yaitu Kecamatan Metro Timur, Kecamatan Metro Utara, Kecamatan Rajabasa, dan Kecamatan Tanjung Senang. Pada penelitian ini akan dianalisis usaha budidaya jamur tiram dengan membedakan pembudidaya jamur tiram ke dalam tiga kategori usaha, sesuai dengan teknis usaha yang diterapkan, yaitu kategori satu adalah pembudidaya yang memproduksi baglog untuk dibudidayakan dan sebagian dijual, kategori dua adalah pembudidaya yang memproduksi baglog untuk dibudidayakan sendiri, dan kategori tiga adalah pembudidaya yang membeli baglog untuk dibudidayakan. Berdasarkan uraian latar belakang sebelumnya, maka penelitian ini bertujuan untuk menganalisis kelayakan finansial, dan risiko usaha budidaya jamur tiram.

\section{METODE PENELITIAN}

Metode yang digunakan dalam penelitian ini adalah metode survei. Penelitian dilakukan di Provinsi Lampung, tepatnya di Kota Metro dan Bandar Lampung. Pemilihan lokasi dilakukan secara sengaja (purposive) dengan pertimbangan bahwa daerah tersebut memliki luas panen dan produksi jamur tiram terbesar di Provinsi Lampung. Metode pengambilan sampel adalah metode sensus di mana setiap pembudidaya telah memproduksi jamur tiram minimal lima kali musim tanam. Jumlah responden pada penelitian ini adalah tujuh pembudidaya yang tersebar di empat kecamatan yaitu Kecamatan Metro Utara (Kelurahan Karang Rejo, Banjar Sari dan Purwosari), Metro Timur (Kelurahan Yosodadi), Rajabasa (Kelurahan Rajabasa Jaya) dan Tanjung Senang (Kelurahan Way Kandis).

Pengumpulan data penelitian dilakukan pada bulan Mei 2017. Data yang dikumpulkan terdiri dari data primer, yang diperoleh dari wawancara langsung dengan pembudidaya menggunakan kuisioner, dan data sekunder, diperoleh dari laporan, publikasi dan studi literatur yang relevan melalui instansi yang terkait dengan penelitian.
Metode analisis data yang digunakan adalah metode analisis kuantitatif. Analisis kuantitatif menggunakan analisis statistik dalam mengukur besarnya keuntungan dan kelayakan finansial, analisis sensitivitas, dan analisis risiko.

Analisis finansial dilakukan untuk melihat tingkat keuntungan dan kelayakan usaha budidaya jamur, diukur berdasarkan kriteria investasi menurut Pasaribu (2012). Analisis finansial pada penelitian ini menggunakan umur ekonomis kumbung sebagai investasi utama dalam melakukan budidaya jamur, yaitu 10 tahun dan tingkat suku bunga sembilan persen per tahun pada tahun 2017, dengan jenis KUR Ritel Bank BRI untuk kategori usaha satu dan dua (investasi lebih dari Rp25.000.000,00), sedangkan KUR Mikro digunakan untuk kategori usaha tiga (investasi kurang dari Rp25.000.000,00). Besarnya tingkat suku bunga untuk kedua jenis KUR adalah sama, yang membedakan adalah nilai pinjaman yang bisa didapatkan (Bank Rakyat Indonesia 2017).

Kriteria investasi yang digunakan pada analisis finansial meliputi NPV (Net Present Value), IRR (Internal Rate of Return), Net B/C (Net Benefit Cost Ratio), Gross B/C (Gross Benefit Cost Ratio) dan PP (Payback Period). NPV diperoleh dari selisih antara benefit dengan biaya yang telah disesuaikan pada tingkat suku bunga sembilan persen per tahun.

$\mathrm{NPV}=\sum_{\mathrm{t}=1}^{\mathrm{n}} \frac{\mathrm{Bt}-\mathrm{Ct}}{(1+\mathrm{i})^{\mathrm{t}}}=\sum_{\mathrm{t}=1}^{\mathrm{n}}(\mathrm{Bt}-\mathrm{Ct})(\mathrm{df})$

Keterangan:

$\mathrm{Bt}=$ Jumlah benefit dalam periode tahun $\mathrm{t}$

$\mathrm{Ct}=$ Jumlah biaya dalam periode tahun $\mathrm{t}$

df $=$ Discount factors (sembilan persen per tahun)

$\mathrm{t}=$ Umur ekonomis kumbung (10 tahun)

Kriteria penilaian:

(1) NPV > 0, maka usaha layak diusahakan.

(2) $\mathrm{NPV}=0$, maka usaha dinyatakan impas.

(3) $\mathrm{NPV}<0$, maka usaha tidak layak diusahakan.

IRR merupakan alat ukur untuk mengetahui kemampuan usaha budidaya jamur tiram dalam mengembalikan bunga pinjaman. IRR menunjukkan tingkat suku bunga yang menghasilkan NPV sama dengan nol.

$I R R=i^{\prime}+\frac{N P V^{\prime}}{N P V^{\prime}-N P V "}\left(i^{\prime \prime}-i^{\prime}\right)$ 
Keterangan:

$\mathrm{NPV}^{\prime}=\mathrm{NPV}$ positif

NPV" = NPV positif

i' = Discount rate yang menghasilkan NPV'

i" = Discount rate yang menghasilkan NPV"

Kriteria penilaian:

(1) IRR > i, maka usaha dinyatakan layak.

(2) $\operatorname{IRR}=i$, maka usaha dinyatakan impas.

(3) IRR < i, maka usaha dinyatakan tidak layak.

Net $\mathrm{B} / \mathrm{C}$ diperoleh dari perbandingan antara jumlah NPV bernilai positif dengan jumlah NPV bernilai negatif. Net B/C ini menunjukkan gambaran berapa benefit yang diperoleh dari setiap satu satuan biaya yang dikeluarkan.

Net $\mathrm{B} / \mathrm{C}=\sum_{\mathrm{t}=1}^{\mathrm{n}} \frac{\mathrm{Bt}-\mathrm{Ct}}{(1+\mathrm{i})^{\mathrm{t}}} / \sum_{\mathrm{t}=1}^{\mathrm{n}} \frac{\mathrm{Ct}-\mathrm{Bt}}{(1+\mathrm{i})^{\mathrm{t}}}$

Keterangan:

$\mathrm{Bt}=$ Jumlah benefit dalam periode tahun $\mathrm{t}$

$\mathrm{Ct}=$ Jumlah biaya dalam periode tahun $\mathrm{t}$

$\mathrm{i}=$ Tingkat suku bunga (sembilan persen per tahun)

$\mathrm{t}=$ Umur ekonomis kumbung (10 tahun)

Kriteria penilaian:

(1) Net $\mathrm{B} / \mathrm{C}>1$, maka usaha dinyatakan layak.

(2) Net $\mathrm{B} / \mathrm{C}=1$, maka usaha dinyatakan impas.

(3) Net $\mathrm{B} / \mathrm{C}<1$, maka usaha dinyatakan tidak layak.

Gross B/C merupakan kriteria investasi, baik manfaat maupun biaya menggunakan nilai kotor (gross). Gross B/C diperoleh dari rasio antara jumlah Present Value Benefit (PVB) dengan Present Value Cost (PVC). Kriteria Gross B/C ini lebih menggambarkan pengaruh dari adanya tambahan biaya terhadap tambahan manfaat yang diterima.

Gross $\mathrm{B} / \mathrm{C}=\sum_{\mathrm{t}=1}^{\mathrm{n}} \frac{\mathrm{Bt}}{(1+\mathrm{i})^{\mathrm{t}}} / \sum_{\mathrm{t}=1}^{\mathrm{n}} \frac{\mathrm{Ct}}{(1+\mathrm{i})^{\mathrm{t}}}$.

\section{Keterangan:}

$\mathrm{Bt}=\mathrm{Jumlah}$ benefit bruto pada tahun $\mathrm{t}$

$\mathrm{Ct}=$ Jumlah biaya bruto pada tahun $\mathrm{t}$

$\mathrm{i}=$ Tingkat suku bunga (sembilan persen per tahun)

$\mathrm{t}=$ Umur ekonomis kumbung (10 tahun)

Kriteria penilaian:

(1) Gross B/C > 1, maka usaha dinyatakan layak.

(2) Gross $\mathrm{B} / \mathrm{C}=1$, maka usaha dinyatakan impas.

(3) Gross B/C < 1, maka usaha tidak layak.
Payback Period (PP) digunakan untuk menganalisis lamanya waktu pengembalian dari investasi usaha, karena itu satuan hasilnya bukan persentase, tetapi satuan waktu (bulan, tahun, dan sebagainya).

Payback Period $=\frac{\mathrm{Ko}}{\mathrm{Ab}} \times 1$ tahun

Keterangan:

Ko = Investasi awal

$\mathrm{Ab}=$ Manfaat (benefit) setiap periode

Kriteria penilaian:

1) Bila nilai PP < umur ekonomis kumbung, maka usaha layak untuk diusahakan.

2) Bila nilai PP > umur ekonomis kumbung, maka usaha tidak layak untuk diusahakan.

Analisis sensitivitas dilakukan untuk melihat apa yang terjadi dengan hasil analisis finansial jika terdapat suatu kesalahan atau perubahan dalam perhitungan biaya atau benefit. Analisis sensitivitas diukur dengan menghitung kriteria investasi pada beberapa skenario perubahan yang mungkin terjadi. Analisis sensitivitas juga digunakan sebagai pendekatan menentukan tingkat risiko. Perubahan-perubahan pada budidaya jamur tiram yang terjadi pada daerah penelitian antara lain adalah perubahan atas penurunan harga jual jamur tiram, penurunan produksi jamur tiram, dan kenaikan biaya produksi (penyediaan) baglog. Menurut Gittinger (1993), laju kepekaan dirumuskan sebagai:

Laju kepekaan $=\frac{\left|\frac{\mathrm{X}-\mathrm{Xo}}{\overline{\mathrm{X}}}\right| \times 100 \%}{\left|\frac{\mathrm{Yi}-\mathrm{Yo}}{\overline{\mathrm{Y}}}\right| \times 100 \%}$.

$\mathrm{X}_{\mathrm{i}}=$ Kriteria investasi setelah perubahan

$\mathrm{X}_{\mathrm{O}}=$ Kriteria investasi sebelum perubahan

$\overline{\mathrm{X}}=$ Rata-rata perubahan kriteria investasi

$\mathrm{Y}_{\mathrm{i}}=$ Biaya/jumlah produksi setelah perubahan

$\mathrm{Y}_{\mathrm{O}}=$ Biaya/jumlah produksi sebelum perubahan

$\overline{\mathrm{Y}}=$ Rata-rata perubahan biaya/jumlah produksi

Kriteria laju kepekaan:

(1) Jika laju kepekaan > 1, maka usaha jamur tiram sensitif terhadap perubahan.

(2) Jika laju kepekaan < 1, maka usaha jamur tiram tidak sensitif terhadap perubahan.

Analisis risiko dilakukan untuk mengukur besarnya risiko yang dihadapi oleh pembudidaya dalam melakukan usaha budidaya jamur tiram. Analisis risiko yang diukur adalah risiko produksi 
dan risiko harga. Menurut Djuwendah dan Septiarini (2016), risiko produksi yang paling sering terjadi adalah penurunan volume produksi dengan sumber risiko yang dapat berasal dari dalam maupun luar lingkungan usahatani, sedangkan risiko pemasaran yang dialami pembudidaya berupa penurunan pendapatan yang disebabkan oleh fluktuasi harga dan teknis penjualan yang kurang baik.

Pada penelitian ini risiko produksi diukur berdasarkan data produksi jamur tiram dalam satuan kilogram per baglog, dan risiko harga diukur dengan melihat perubahan harga jual jamur tiram selama lima musim tanam terakhir. Risiko dapat diukur melalui nilai rata-rata (mean), keragaman (variance), simpangan baku (standard deviation), koefisien variasi (coefficient variation) dan batas bawah (Kadarsan 1995).

Nilai rata-rata (mean) dihitung untuk memperoleh rata-rata produksi dan harga jual jamur tiram yang akan digunakan untuk mencari ragam, simpangan baku, koefisien variasi dan batas bawah.

$\mathrm{E}=\frac{\sum_{\mathrm{i}=1}^{\mathrm{n}} \mathrm{Ei}}{\mathrm{n}}$

Keterangan:

$\mathrm{E}=$ Nilai rata-rata (mean)

$\mathrm{Ei}=$ Hasil produksi jamur tiram dan harga jual per musim tanam

$\mathrm{n}=$ Lima musim tanam

Keragaman (variance) menunjukkan bahwa semakin kecil nilai variance, maka semakin kecil risiko yang dihadapi usaha jamur tiram tersebut. Simpangan baku (standard deviation) berbanding lurus dengan risiko sehingga apabila nilai standar deviasi semakin besar maka risiko yang dihadapi semakin besar pula.

$\mathrm{V}^{2}=\frac{\sum_{\mathrm{i}=1}^{\mathrm{n}}(\mathrm{Ei}-\mathrm{E})^{2}}{(\mathrm{n}-1)}$

$\mathrm{V}=\sqrt{\frac{\sum_{\mathrm{i}=1}^{\mathrm{n}}(\mathrm{Ei}-\mathrm{E})^{2}}{(\mathrm{n}-1)}}$.

Keterangan:

$\mathrm{V}^{2}=$ Ragam

$\mathrm{V}=$ Simpangan baku

$\mathrm{E}=$ Nilai rata-rata (mean)

$\mathrm{Ei}=$ Produksi atau harga jual per musim tanam
Nilai risiko dalam memberikan suatu hasil dapat dipakai ukuran koefisien variasi, sedangkan penentuan batas bawah penting dilakukan untuk mengetahui jumlah hasil terbawah dari tingkat hasil yang diharapkan.

$\mathrm{CV}=\frac{\mathrm{V}}{\mathrm{E}}$

$\mathrm{L}=\mathrm{E}-2 \mathrm{~V}$

Keterangan:

$\mathrm{CV}=$ Koefisien variasi

$\mathrm{V}=$ Simpangan baku

$\mathrm{E}=$ Mean

$\mathrm{L}=$ Batas bawah

\section{HASIL DAN PEMBAHASAN}

\section{Karakteristik Responden}

Pada penelitian ini, pembudidaya kategori pertama berjumlah tiga pembudidaya, kategori dua berjumlah dua pembudidaya dan kategori tiga berjumlah dua pembudidaya. Rentang usia pembudidaya adalah 32 sampai 64 tahun, dengan mayoritas pembudidaya sebesar 71,43 persen berusia antara 32 sampai dengan 42 tahun. Tingkat pendidikan sudah tergolong tinggi, yaitu sarjana, sedangkan pendidikan terendah adalah SMA. Pengalaman budidaya jamur tiram berkisar antara tiga sampai dengan enam tahun, dengan usaha budidaya terbaru dimulai tahun 2014, sedangkan yang terlama dimulai tahun 2011. Tanggungan keluarga oleh pembudidaya berkisar antara dua hingga lima orang. Kapasitas baglog yang dibudidayakan oleh pembudidaya berkisar antara 5.000 - 50.000 unit.

\section{Usaha Budidaya Jamur Tiram}

Budidaya jamur tiram dimulai dari penyediaan baglog (media tanam) dengan proses pembuatannya meliputi: pencampuran bahan baku (serbuk kayu, dedak, dolomit (kapur) dan air), pengemasan dalam plastik baglog, sterilisasi (pembakaran), pendinginan, inokulasi (pembibitan), dan inkubasi (perambatan miselium). Setelah miselium merambat sempurna (baglog berubah menjadi putih), maka masuk dalam proses budidaya. Kegiatan pada tahap budidaya adalah penyiraman, pemeliharaan dan panen. Satu periode budidaya dilakukan selama kurang lebih enam bulan dengan waktu pemanenan selama empat bulan. 
Tabel 1. Sebaran biaya investasi dan usaha budidaya jamur tiram berdasarkan kategori usaha, tahun 2017

\begin{tabular}{cccr}
\hline Keterangan & Kategori 1 & Kategori 2 & Kategori 3 \\
\hline Kumbung (Rp) & 27.733 .333 & 30.000 .000 & 11.500 .000 \\
Peralatan (Rp) & 19.225 .556 & 15.310 .000 & 3.017 .500 \\
\hline Jumlah & 46.958 .889 & 45.310 .000 & 14.517 .500 \\
\hline
\end{tabular}

Pada Tabel 1 dapat dilihat bahwa biaya investasi terdiri dari biaya kumbung (rumah jamur) dan peralatan. Biaya investasi terbesar berada pada kategori satu, karena memproduksi baglog lebih banyak (dibudidayakan dan sebagian dijual), sedangkan biaya investasi terendah pada kategori tiga, karena hanya membudidayakan jamur dengan membeli baglog yang sudah jadi, sehingga tidak mengeluarkan biaya peralatan yang banyak.

Biaya operasional terdiri dari biaya variabel dan biaya tetap. Biaya variabel mencakup bahan baku dan tenaga kerja. Bahan baku terdiri dari serbuk kayu, bekatul, kapur, bibit, plastik baglog, karet gelang, koran, cincin baglog, kayu bakar dan plastik jamur. Biaya tenaga kerja kategori satu dan dua, yaitu persiapan bahan baku, sterilisasi dan inkubasi masing-masing Rp15.000,00 per hari, pengemasan dan inokulasi masing-masing berkisar antara Rp125,00 - Rp150,00 per baglog dan Rp100,00 - Rp130,00 per baglog, tenaga kerja budidaya hingga panen Rp50.000,00 per hari, sedangkan biaya kategori tiga terdiri dari penyusunan baglog yang sudah jadi ke rak dengan upah Rp50,00 per baglog dan biaya budidaya Rp50.000,00 per hari. Biaya tetap terdiri dari biaya listrik dan pajak.

Pada Tabel 2 dapat dilihat sebaran biaya, penerimaan dan pendapatan rata-rata, dengan penerimaan kategori satu diperoleh dari penjualan baglog dan jamur tiram, sedangkan penerimaan kategori dua dan tiga berasal dari penjualan jamur tiram. Jika dilihat dari pendapatan, maka kategori dua lebih menguntungkan, karena fokus dalam menjual jamur tiram yang memiliki harga lebih tinggi dibandingkan harga jual baglog, yaitu harga baglog Rp2.200,00 per unit dan harga jamur tiram adalah Rp10.000,00 per kilogram pada tahun 2017.

Tabel 2. Sebaran biaya, penerimaan dan pendapatan rata-rata berdasarkan kategori usaha, tahun 2017

\begin{tabular}{lccr}
\hline \multicolumn{1}{c}{ Keterangan } & Kategori 1 & Kategori 2 & \multicolumn{1}{c}{ Kategori 3 } \\
\hline Biaya (Rp) & 69.540 .936 & 57.812 .812 & 29.926 .107 \\
Penerimaan $(\mathrm{Rp})$ & 94.715 .498 & 98.882 .877 & 32.775 .798 \\
Pendapatan $(\mathrm{Rp})$ & 25.174 .563 & 41.070 .065 & 2.849 .690 \\
\hline
\end{tabular}

Tabel 3. Sebaran hasil analisis kelayakan finansial berdasarkan kategori usaha, tahun 2017

\begin{tabular}{lrrr}
\hline \multicolumn{1}{c}{ Kriteria } & Kategori 1 & Kategori 2 & Kategori 3 \\
\hline IRR $(\%)$ & 35,5 & 26,7 & Ket \\
NPV(Rp) & 150.594 .450 & 224.508 .689 & 15.514 .459 Layak \\
PP (MT) & 4,39 & 7,46 & 10,72 Layak \\
GrossB/C & 1,34 & 1,60 & 1,08 Layak \\
Net B/C & 6,64 & 8,69 & 3,05 Layak \\
\hline
\end{tabular}

\section{Analisis Kelayakan Finansial}

Pada Tabel 3 dapat dilihat sebaran hasil analisis kelayakan finansial usaha budidaya jamur tiram. Perhitungan finansial pada budidaya jamur tiram disajikan dalam bentuk musim tanam, sehingga dengan umur ekonomis 10 tahun memiliki jumlah musim tanam sebanyak 20 musim tanam. Analisis finansial dihitung dengan menggunakan metode discounting (untuk mengetahui nilai sekarang dari sejumlah uang yang akan diterima dalam suatu periode di masa mendatang). Hasil analisis kelayakan finansial usaha budidaya jamur tiram pada tiga kategori usaha di Kota Metro dan Bandar Lampung adalah layak dan menguntungkan. Penelitian ini sejalan dengan Mukti, Haryono, dan Marlina (2016) yang menunjukkan bahwa hasil analisis finansial pada usahatani jamur tiram putih di Kabupaten Lampung Barat layak untuk dikembangkan.

Tujuan dalam melakukan budidaya jamur tiram adalah untuk memperoleh hasil netto (net benefit) maksimum yang dapat dicapai dengan investasi modal. Kategori usaha yang memberikan manfaat yang paling besar adalah kategori dua yang berfokus dalam pemeliharaan dan penjualan jamur tiram. Hal itu dapat dilihat dari nilai NPV, Net B/C dan Gross B/C yang diperoleh kategori dua lebih besar dibandingkan kategori satu dan tiga.

\section{Analisis Sensitivitas}

\section{a. Penurunan Harga Jual Jamur Tiram}

Harga jual jamur tiram merupakan salah satu bentuk ketidakpastian dalam budidaya jamur tiram, karena banyaknya produsen jamur tiram yang memasuki pasar jamur yang potensial, sehingga semakin meningkatnya produksi jamur tiram untuk permintaan yang relatif tetap, maka akan menurunkan harga dan masyarakat sebagai konsumen juga mengharapkan lebih banyak produsen untuk bersaing, sehingga dapat membeli jamur tiram dengan harga yang lebih murah. Menurut Candra, Hepiana, dan Situmorang (2014), penentuan harga jamur 
ditentukan berdasarkan kualitas jamur tiram, seperti kadar air, tingkat kecerahan dan ukuran buah, sehingga harga jamur tiram akan cenderung turun jika jamur tidak berkualitas.

Analisis sensitivitas untuk penurunan harga jual jamur tiram menggunakan dua skenario, yaitu skenario satu didasari pada rata-rata penurunan harga jual jamur dan skenario kedua didasari pada penurunan harga jual tertinggi yang pernah terjadi. Penurunan harga pada skenario satu adalah satu persen (untuk tiga kategori usaha). Penurunan harga tertinggi yang pernah terjadi pada skenario dua adalah enam persen (kategori satu) dan lima persen (kategori dua dan kategori tiga). Hasil analisis sensitivitas terhadap penurunan harga jual jamur tiram dapat dilihat pada Tabel 4.

Tabel 4. Sebaran hasil analisis sensitivitas terhadap penurunan harga berdasarkan kategori usaha, tahun 2017

\begin{tabular}{|c|c|c|c|c|c|}
\hline $\begin{array}{l}\text { Kate } \\
\text { gori }\end{array}$ & Kriteria & Awal & Perubahan & LK & Ket \\
\hline \multicolumn{6}{|c|}{$\begin{array}{l}\text { Penurunan Harga Jual Jamur Tiram (Skenario 1) } \\
\text { (Sko }\end{array}$} \\
\hline \multirow{5}{*}{$\begin{array}{l}1 \\
\text { (a) }\end{array}$} & IRR (\%) & 35,5 & 34,9 & 1,71 & $\mathrm{~S}$ \\
\hline & NPV (Rp) & 150.594 .450 & 148.120 .093 & 1,65 & S \\
\hline & $\mathrm{PP}(\mathrm{MT})$ & 4,39 & 4,45 & $-1,28$ & $\mathrm{~S}$ \\
\hline & Gross B/C & 1,34 & 1,33 & 0,14 & TS \\
\hline & Net B/C & 6,64 & 6,55 & 1,49 & $\mathrm{~S}$ \\
\hline \multirow{5}{*}{$\begin{array}{l}2 \\
\text { (a) }\end{array}$} & IRR (\%) & 26,7 & 26,2 & 1,82 & $\mathrm{~S}$ \\
\hline & NPV (Rp) & 224.508 .689 & 217.817 .581 & 3,01 & $\mathrm{~S}$ \\
\hline & PP (MT) & 7,46 & 7,53 & $-0,90$ & TS \\
\hline & Gross B/C & 1,60 & 1,58 & 1,12 & $\mathrm{~S}$ \\
\hline & Net B/C & 8,69 & 8,43 & 3,12 & $\mathrm{~S}$ \\
\hline \multirow{5}{*}{$\begin{array}{l}3 \\
\text { (a) }\end{array}$} & IRR (\%) & 19,5 & 17,6 & 10,25 & $\mathrm{~S}$ \\
\hline & NPV (Rp) & 15.514 .459 & 13.236 .618 & 15,77 & S \\
\hline & PP (MT) & 10,72 & 11,45 & $-6,57$ & S \\
\hline & Gross B/C & 1,08 & 1,07 & 1,07 & $\mathrm{~S}$ \\
\hline & Net B/C & 3,05 & 2,73 & 10,84 & $\mathrm{~S}$ \\
\hline \multicolumn{6}{|c|}{ Penurunan Harga Jual Jamur Tiram (Skenario 2) } \\
\hline \multirow{5}{*}{$\begin{array}{l}1 \\
\text { (b) }\end{array}$} & IRR $(\%)$ & 35,5 & 32,0 & 1,69 & S \\
\hline & NPV (Rp) & 150.594 .450 & 138.174.934 & 1,39 & $S$ \\
\hline & PP (MT) & 4,39 & 4,77 & $-1,33$ & $\mathrm{~S}$ \\
\hline & Gross B/C & 1,34 & 1,31 & 0,34 & TS \\
\hline & Net B/C & 6,64 & 6,15 & 1,26 & $\mathrm{~S}$ \\
\hline \multirow{5}{*}{$\begin{array}{l}2 \\
(\mathrm{c})\end{array}$} & IRR $(\%)$ & 26,7 & 24,3 & 1,84 & $\mathrm{~S}$ \\
\hline & NPV (Rp) & 224.508 .689 & 193.918.926 & 2,85 & $\mathrm{~S}$ \\
\hline & PP (MT) & 7,46 & 7,84 & $-0,96$ & TS \\
\hline & Gross B/C & 1,60 & 1,52 & 1,02 & $\mathrm{~S}$ \\
\hline & Net B/C & 8,69 & 7,48 & 2,94 & $\mathrm{~S}$ \\
\hline \multirow{5}{*}{$\begin{array}{l}3 \\
\text { (c) }\end{array}$} & IRR (\%) & 19,5 & 9,6 & 13,37 & $\mathrm{~S}$ \\
\hline & NPV (Rp) & 15.514 .459 & 4.748 .369 & 20,72 & S \\
\hline & $\mathrm{PP}(\mathrm{MT})$ & 10,72 & 15,69 & $-7,33$ & S \\
\hline & Gross B/C & 1,08 & 1,02 & 1,01 & S \\
\hline & Net B/C & 3,05 & 1,57 & 12,53 & S \\
\hline \multicolumn{6}{|c|}{ Keterangan: } \\
\hline \multirow{2}{*}{\multicolumn{6}{|c|}{$\begin{array}{l}\mathrm{a}=\text { Penurunan harg } \\
\mathrm{b}=\text { Penurunan harg }\end{array}$}} \\
\hline & & & & & \\
\hline & enurunan ha & jual jamur ti & lima persen & & \\
\hline
\end{tabular}

Pada Tabel 4 dapat dilihat bahwa sebagian besar kriteria investasi pada tiga kategori usaha sensitif terhadap penurunan harga jual jamur tiram pada skenario satu maupun skenario dua, dengan perubahan nilai kriteria investasi yang masih layak dan menguntungkan hingga penurunan harga jual jamur tiram tertinggi yang pernah terjadi. Jika hasil analisis sensitivitas penurunan harga jual jamur tiram digunakan sebagai pendekatan untuk menentukan tingkat risiko, maka kategori dua menunjukkan jarak (range) perubahan nilai IRR yang lebih kecil, artinya investasi kategori dua lebih kecil risikonya dibandingkan dengan investasi kategori satu dan tiga.

\section{b. Penurunan Produksi Jamur Tiram}

Jamur tiram merupakan salah satu produk pertanian yang bergantung pada alam dan seringkali terjadi kegagalan produksi. Penyebab penurunan produksi jamur tiram meliputi: cuaca (terlalu panas atau terlalu dingin), serangan hama ulat dan penyakit. Penurunan produksi jamur tiram akan berdampak pada penurunan pendapatan yang diterima oleh pembudidaya, sehingga penurunan produksi jamur tiram perlu dianalisis sensitivitasnya. Analisis sensitivitas pada penelitian ini didasari pada rata-rata penurunan produksi jamur tiram, yaitu penurunan produksi jamur tiram pada kategori satu dan dua adalah 17 persen dan kategori tiga adalah tujuh persen. Hasil analisis sensitivitas penurunan produksi jamur tiram dapat dilihat pada Tabel 5.

Tabel 5. Sebaran hasil analisis sensitivitas terhadap penurunan produksi berdasarkan kategori usaha, tahun 2017

\begin{tabular}{rlrrrc}
\hline $\begin{array}{r}\text { Kate } \\
\text { gori }\end{array}$ & Kriteria & \multicolumn{1}{c}{ Awal } & Perubahan & LK & Ket \\
\hline \multirow{4}{*}{1 IRR (\%) } & 35,5 & 26,0 & 1,67 & $\mathrm{~S}$ \\
& NPV (Rp) & 150.594 .450 & 116.295 .583 & 1,38 & $\mathrm{~S}$ \\
& PP (MT) & 4,39 & 6,29 & $-1,92$ & $\mathrm{~S}$ \\
& Gross B/C & 1,34 & 1,26 & 0,32 & TS \\
& Net B/C & 6,64 & 5,28 & 1,23 & $\mathrm{~S}$ \\
\hline \multirow{4}{*}{2} & IRR (\%) & 26,7 & 18,2 & 2,05 & $\mathrm{~S}$ \\
& NPV (Rp) & 224.508 .689 & 122.222 .960 & 3,18 & $\mathrm{~S}$ \\
PP (MT) & 7,46 & 8,96 & $-0,98$ & $\mathrm{TS}$ \\
& Gross B/C & 1,60 & 1,33 & 1,01 & $\mathrm{~S}$ \\
& Net B/C & 8,69 & 4,50 & 3,42 & $\mathrm{~S}$ \\
\hline \multirow{4}{*}{3} & IRR (\%) & 19,5 & 4,78 & 16,73 & $\mathrm{~S}$ \\
& NPV (Rp) & 15.514 .459 & 504.244 & 25,84 & $\mathrm{~S}$ \\
PP (MT) & 10,72 & 19,39 & $-7,94$ & $\mathrm{~S}$ \\
& Gross B/C & 1,08 & 1,00 & 1,01 & $\mathrm{~S}$ \\
& Net B/C & 3,05 & 1,06 & 13,39 & $\mathrm{~S}$ \\
\hline
\end{tabular}


Pada Tabel 5 dapat dilihat bahwa penurunan produksi jamur menyebabkan penurunan nilai kriteria investasi pada tiga kategori usaha. Usaha budidaya kategori satu dan dua masih layak untuk diusahakan, sedangkan usaha budidaya kategori tiga masih layak pada kriteria investasi NPV, PP, Gross B/C dan Net B/C, namun pada kriteria IRR tidak layak, karena lebih kecil dari tingkat suku bunga sembilan persen. Dalam mengatasi kerugian akibat penurunan produksi jamur tiram, pembudidaya melakukan strategi agronomi, meliputi penyiraman kumbung pada cuaca panas, pengeringan jamur yang lembek serta pembersihan kumbung dan baglog secara rutin.

\section{c. Kenaikan Biaya Baglog}

Biaya produksi budidaya jamur tiram yang utama adalah biaya pembuatan atau pengadaan baglog sebagai media tanam jamur. Kenaikan biaya baglog akan mempengaruhi pendapatan, karena semakin tinggi biaya baglog akan semakin kecil keuntungan yang diterima oleh pembudidaya. Biaya pembuatan baglog hanya dikeluarkan oleh pembudidaya kategori satu dan dua, sedangkan kategori tiga yang tidak membuat baglog sendiri, maka diasumsikan membeli baglog pada kategori satu. Analisis sensitivitas terhadap kenaikan biaya baglog didasarkan pada trend kenaikan biaya pembuatan atau penyediaan baglog per unit. Kenaikan biaya baglog kategori satu dan tiga adalah enam persen, sedangkan kenaikan biaya baglog kategori dua adalah lima persen.

Tabel 6. Sebaran hasil analisis sensitivitas terhadap kenaikan biaya baglog berdasarkan kategori usaha, tahun 2017

\begin{tabular}{rlrrrc}
\hline $\begin{array}{c}\text { Kate } \\
\text { gori }\end{array}$ & Kriteria & \multicolumn{1}{c}{ Awal } & Perubahan & LK & Ket \\
\hline \multirow{4}{*}{1} & IRR (\%) & 35,5 & 31,5 & $-2,18$ & $\mathrm{~S}$ \\
& NPV (Rp) & 150.594 .450 & 125.642 .336 & $-3,27$ & $\mathrm{~S}$ \\
& PP (MT) & 4,39 & 4,69 & 1,19 & $\mathrm{~S}$ \\
& Gross B/C & 1,34 & 1,27 & $-0,98$ & $\mathrm{TS}$ \\
& Net B/C & 6,64 & 5,65 & $-2,93$ & $\mathrm{~S}$ \\
\hline \multirow{4}{*}{2} & IRR (\%) & 26,7 & 25,0 & $-1,49$ & $\mathrm{~S}$ \\
& NPV (Rp) & 224.508 .689 & 207.416 .510 & $-1,73$ & $\mathrm{~S}$ \\
& PP (MT) & 7,46 & 7,72 & 0,73 & $\mathrm{TS}$ \\
& Gross B/C & 1,60 & 1,53 & $-0,98$ & $\mathrm{TS}$ \\
& Net B/C & 8,69 & 7,86 & $-2,21$ & $\mathrm{~S}$ \\
\hline \multirow{4}{*}{3} & IRR (\%) & 19,5 & 11,39 & $-11,36$ & $\mathrm{~S}$ \\
& NPV (Rp) & 15.514 .459 & 6.421 .759 & $-17,86$ & $\mathrm{~S}$ \\
PP (MT) & 10,72 & 14,73 & 6,79 & $\mathrm{~S}$ \\
& Gross B/C & 1,08 & 1,03 & $-0,97$ & TS \\
& Net B/C & 3,05 & 1,78 & -1129 & $\mathrm{~S}$ \\
\hline
\end{tabular}

Pada Tabel 6 dapat dilihat bahwa peningkatan biaya baglog menunjukkan bahwa usaha budidaya masih layak dan menguntungkan pada tiga kategori usaha. Kriteria investasi yang tidak sensitif terhadap kenaikan biaya baglog adalah Gross B/C dan PP. Hasil analisis sensitivitas dapat menjadi pendekatan untuk menentukan tingkat risiko usaha. Kategori usaha dua menunjukkan jarak (range) perubahan IRR yang lebih kecil akibat adanya perubahan kenaikan biaya baglog, artinya investasi kategori dua lebih kecil risikonya dibanding dengan kategori usaha lainnya.

\section{Analisis Risiko}

Risiko produksi berkaitan dengan penurunan hasil jamur tiram yang besarnya berfluktuasi pada setiap musim tanam. Penyebab terbesar penurunan hasil jamur tiram pada daerah penelitian adalah serangan hama ulat, penyakit, kontaminasi jamur dan cuaca. Perubahan harga jual jamur juga terkadang dipengaruhi oleh perubahan cuaca dan ketersediaan jamur tiram di pasar. Harga jamur tiram terendah hingga tertinggi adalah Rp9.000,00 - Rp11.000,00 per kilogram. Saat musim penghujan, produksi jamur tiram biasanya akan tinggi, sehingga harga akan turun, sedangkan saat musim kemarau, produksi jamur tiram relatif sedikit, sehingga harga cenderung naik.

Hubungan risiko dengan keuntungan diukur dengan koefisien variasi (CV) dan batas bawah keuntungan (L). Nilai CV merupakan perbandingan antara risiko yang harus ditanggung dengan jumlah keuntungan yang akan diperoleh. Semakin besar nilai CV artinya risiko yang harus ditanggung semakin besar dibanding dengan keuntungannya. Nilai batas bawah (L) menunjukkan nilai nominal keuntungan terendah yang mungkin diterima.

Tabel 7. Sebaran hasil analisis risiko produksi dan harga berdasarkan kategori usaha selama lima musim tanam terakhir, tahun 2017

\begin{tabular}{lcrr}
\hline \multicolumn{1}{c}{ Keterangan } & Kategori 1 & Kategori 2 & Kategori 3 \\
\hline \multicolumn{4}{c}{ Risiko Produksi } \\
\hline Nilai tengah (E) & 0,2939 & 0,3197 & 0,3335 \\
Ragam/var. (V ${ }^{2}$ ) & 0,0136 & 0,0018 & 0,0018 \\
Simpangan baku (V) & 0,0995 & 0,0306 & 0,0421 \\
Koef. variasi (CV) & 0,3596 & 0,1020 & 0,1263 \\
Batas bawah (L) & 0,0950 & 0,2585 & 0,2493 \\
\hline \multicolumn{4}{c}{ Risiko Harga } \\
\hline Nilai tengah (E) & 10.000 & 10.000 & 9.800 \\
Ragam/var. (V ${ }^{2}$ ) & 0,00 & 0,00 & 150.000 \\
Simpangan baku (V) & 0,00 & 0,00 & 274 \\
Koef. variasi (CV) & 0,00 & 0,00 & 0,0285 \\
Batas bawah (L) & 10.000 & 10.000 & 9.252 \\
\hline
\end{tabular}


Pada Tabel 7 dapat dilihat bahwa tingkat risiko produksi yang paling besar selama lima musim tanam terakhir dilihat dari nilai CV adalah kategori usaha satu. Hasil analisis risiko harga menunjukkan bahwa tingkat risiko harga lebih kecil jika dibandingkan dengan tingkat risiko produksi. Hal itu dikarenakan pasar jamur tiram masih belum jenuh sehingga penurunan harga tidak terlalu besar. Oleh karena itu, jika dilihat dari batas bawah (L) yang bertanda positif $(L \geq 0)$ dan $\mathrm{CV} \leq 0,5$, menunjukkan bahwa pembudidaya pada tiga kategori usaha akan terhindar dari risiko.

\section{KESIMPULAN}

Usaha budidaya jamur tiram di Kota Metro dan Bandar Lampung merupakan unit usaha yang menguntungkan dan layak untuk dikembangkan serta memiliki risiko yang kecil.

\section{DAFTAR PUSTAKA}

Bank Rakyat Indonesia. 2017. Kredit Usaha Rakyat BRI. http://bri.co.id/subpage?id=45 [8 November 2017].

Candra R, Hepiana DA, dan Situmorang S. 2014. Analisis usahatani dan pemasaran jamur tiram dengan cara konvensional dan jaringan (multi level marketing) di Provinsi Lampung. JIIA. 2 (1): 38-47. http://jurnal.fp.unila.ac.id/index. php/ JIA/article/view/559/521. [4 Januari 2017]
Chazali S dan Pratiwi PS. 2009. Usaha Jamur Tiram Skala Rumah Tangga. Penebar Swadaya. Yogyakarta.

Dinas Pertanian Tanaman Pangan dan Hortikultura. 2016. Perkembangan Luas Panen dan Produksi Tanaman Jamur Menurut Kabupaten/Kota di Provinsi Lampung. Dinas Pertanian Tanaman Pangan dan Hortikultura. Bandar lampung.

Djuwendah E dan Septiarini E. 2016. Manajemen risiko usahatani jamur tiram putih dalam upaya mempertahankan pendapatan petani. Paspalum, 4 (2): 11-22. http://journal.unwim. ac.id/index.php/paspalum/article/download/26 126. [8 November 2017]

Gittinger JP. 1993. Analisis Ekonomi ProyekProyek Pertanian. UI Press. Jakarta.

Kadarsan HW. 1995. Keuangan Pertanian dan Pembiayaan Perusahaan Agribisnis. Gramedia Pustaka Utama. Jakarta.

Kementerian Pertanian. 2016. Basis Data Statistik Pertanian. http://aplikasi.pertanian.go.id/bdsp / index.asp [9 Agustus 2017].

Mukti OP, Haryono D, dan Marlina L. 2016. Analisis finansial dan strategi pengembangan usahatani jamur tiram putih di Desa Pampangan Kecamatan Sekincau Lampung Barat. JIIA, 5 (1): 31-39. http://jurnal.fp.uni la.ac.id/index.php/JIA/article/view/1672/1498. [8 November 2017]

Pasaribu AM. 2012. Perencanaan dan Evaluasi Proyek Agribisnis : Konsep dan Aplikasi. Lily Publisher. Yogyakarta. 